\title{
CHALLENGES OF THE SUSTAINABILITY OF HUNGARIAN DISTRICT HEAT SUPPLIERS - SPECIFICITIES OF THE REPLACEMENT OF ASSETS IN THE DISTRICT HEAT SECTOR
}

\author{
Gábor Béla Süveges \\ assistant professor, University of Miskolc, Institute of Accounting and Finance \\ 3515 Miskolc, Miskolc-Egyetemváros, e-mail: suveges.gabor@uni-miskolc.hu
}

\begin{abstract}
The aim of the study is to highlight an area of regulation of district heat suppliers that needs to be addressed in order to achieve sustainable, long-term, and safe operation. Fixed assets make up the largest proportion of the asset structure of companies carrying out district heating supply activities. In order to ensure sustainable, long-term, and safe operation it is important to replace these assets on a regular basis. According to my calculations though, in the period of the study the investment activity in the sector, considering the average age of the assets used in the district heating supply, was not satisfactory. The current regulatory and support system does not encourage replacement, improvements and modernization.
\end{abstract}

Keywords: district heat suppliers, depreciation, replacement of assets, sustainability

\section{Introduction}

The national economic significance of the Hungarian district heat sector with its nearly 680 thousand fee payers is unquestionable, making studies of the sector relevant. It is further strengthened by the exciting changes in the operational and macro environment of these companies in the last decade. I think the analysis of the financial statements of the sector is a field of research which makes it possible to obtain important information in order to gain an accurate understanding of the sector. Advantages of district heat can be interpretated at the national economy level, however, it also has social advantages thanks to its environmentally friendly solutions [1]. Due to environmental and climate protection, its developments primarily affect the society as a whole and the improvement of its general quality of life, therefore it can properly be considered a social innovation [2].

The aim of the study is to highlight an area of regulation of district heat suppliers that needs to be addressed in order to achieve sustainable, long-term and safe operation. Accordingly, it describes the degree of depreciation of the district heating sector and provides an answer as to whether this rate is appropriate.

\section{Theoretical background}

In order to reach the goals of a company and its stakeholders and to supervise the process of reaching them it is important to have information [3]. The traditional financial accounting indicators serve as a good basis to analyse the pecuniary, financial and profitability situation of industrial sectors or corporations [4][5]. Data available through the financial statements provide an opportunity to create the image of a company. "Financial indicators indication the fulfillment of financial goals can show the 
economic position of the company and help us to understand the economic, causal, market, etc. relations" ([6] p.125)].

Examination of the balance sheet can provide an opportunity to analyze the company's financial position. It can be carried out vertically (when either the asset side or the source side is a source of information) and horizontally, when information from both the asset and the source sides are used to calculate measures [7]. There are no generally accepted rates for asset values as they vary from sector to sector and may also vary from period to period. Based on the studies of Illés [1], in the late 1990s, the "most valuable asset of heat supply companies" was the district heating network, which accounted for $67 \%$ of the total fixed assets in the case of Fövárosi Távfütő Müvek (Capital District Heating Plants)" ([1] p.25). Similarly, no general resolution can be provided about the optimal capital structure, however, "most of the professional sources state that it is desirable that the equity is not less than one third of the resources..., and that the ratio of equity to all sources is $30-40 \%$ for Hungarian companies" ([8], p.32; [9]).

The book value of durable assets is regulated by Act C of 2000 on Accounting in Hungary [10][11], while the regulation at the international level includes IAS $16^{1}$ [11]. In order for companies to be able to maintain their operations on a permanent basis, they must ensure that their durable assets are replaced and they must also ensure the necessary sources for a possible expansion. The possibility of enforcing these factors in prices can be a key issue for public service providers.

A milestone in the regulation of the prices of district heat supply was Decree of the Minister of National Development no. 50/2011 (September 30) on determining the price of district heat that is sold to district heat suppliers and the charge of district heating supply provided for household consumers and specially treated institutions. The price of heat sold to private consumers and institutions of special status, as the highest administrative price, is determined by the Minister of National Development on the basis of the recommendation of the Hungarian Energy and Public Utility Regulatory Authority. Profit margin was set for district heat suppliers and district heat producers. The calculation takes a reasonable profit into account as well that is calculated upon the companies own capital. in terms of the reasonable profit a limit has been determined that equals $2 \%$ of accounted gross asset value related to district heat production and supply as shown in the audited accounting unbundle of the 31st of December of the year before the given year. The regulation also laid down that "the district heat supplier must invest its profit above the profit margin to increase the energy efficiency or to reduce the cost of district heat supply and of district heat production within two years from the realization of the profit above the profit margin. The realization of the investment is monitored by HEA (Hungarian Energy and Public Utility Regulatory Authority)". The amount of profit above the profit margin that is not used for investment should be taken into account in the subsequent price preparation as a justified cost-reducing item, thus giving companies an incentive to indeed invest this part of the profit [13].

\section{Research methods}

\subsection{Methodology}

I carried out an empirical research based on representative sample to analyze the operational and management characteristics of the district heating sector. The methods used in choosing the data and sample were applied in accordance with the general recommendations of statistical and analytical

\footnotetext{
${ }^{1}$ The concepts that need to be taken into consideration in this field include initial recognition, depreciation, revaluation, derecognition (disposals).
} 
publications and theories. The database used for the analysis includes the companies' annual reports from 2013 to 2017. Nowadays in Hungary, 89 companies provide district heating service in 93 settlements. Of these, 72 companies were included in the examined population. It is important to point out that the sampling was representative of the whole population. The technical procedure of the analysis was carried out using the Excel program in Microsoft Office 365 ProPlus and SPSS 24. As for the methodology of the analysis, Excel provided the opportunity to carry out descriptive statistical analysis [14] and the SPSS software package made it possible to carry out more complex analysis.

\subsection{Results}

Initially, I checked whether the fixed assets were indeed the most valuable assets of the heat suppliers. To illustrate this, I formed distribution ratios by owner, which is illustrated in the following figure:

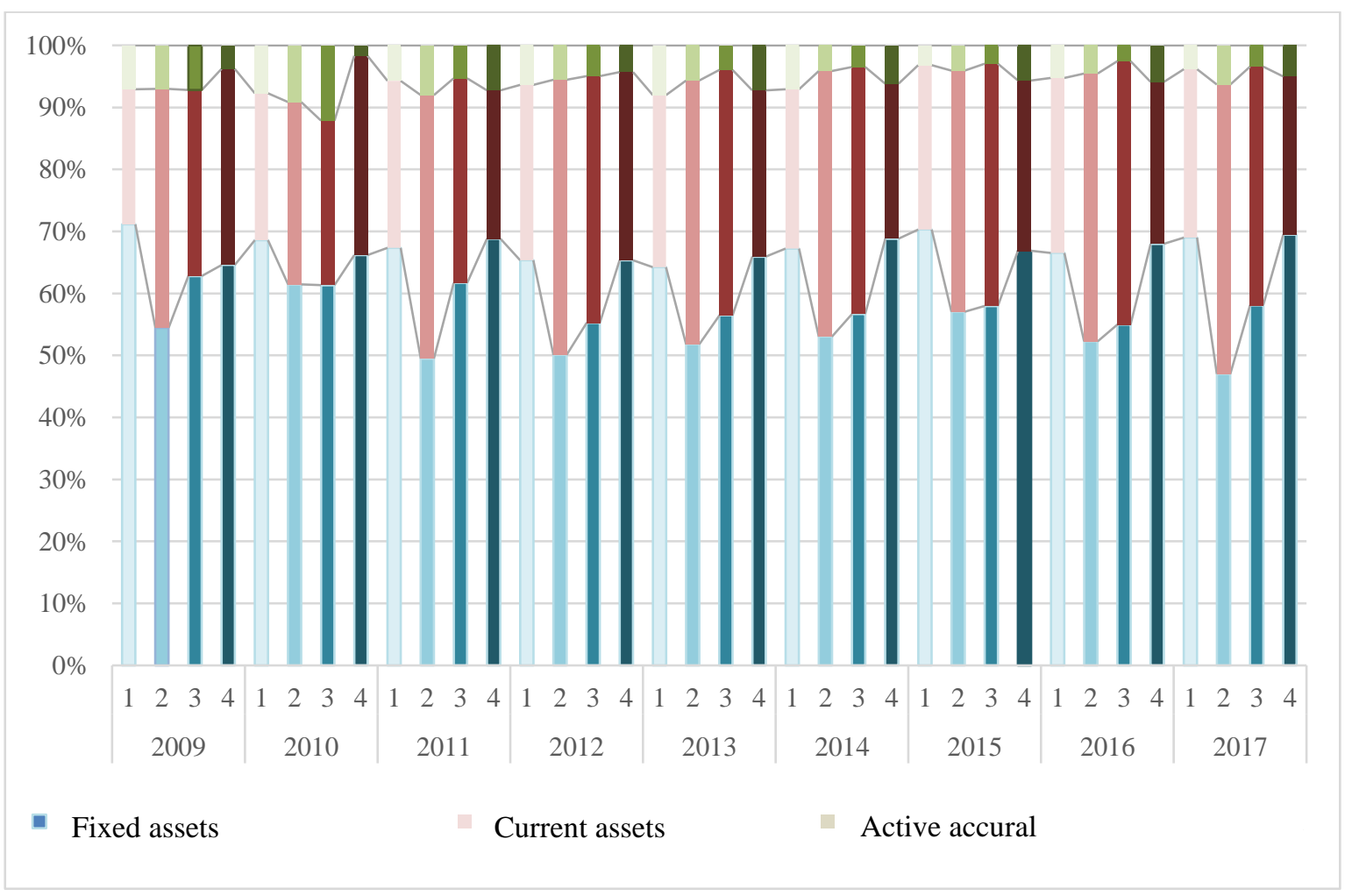

Figure 1. Asset structure by owner type (1: owned by local municipality, 2: in majority privately owned, 3: fiduciary owned, 4: FÖTÁV (owned by local municipality))

\section{Source: own compilation}

Based on the data of the reports from the examined nine years, the average proportion of fixed assets of the examined companies exceeded $60 \%$ according to regular reports each year. As expected, most of the corporate assets are indeed provided by durable assets. It is worth noting that when the reports separated from accounting point of view are examined, which more accurately describe the asset structure required for district heating, the values are a few percentage points lower in the examined years. However, this does not affect the finding that the most valuable part of the companies' assets is 
infrastructure necessary to provide the service [15]. Accordingly, their replacement and preventing any disruption of operations require important resources and responsible management [16]. The ratio of fixed assets of the examined companies vary enormously, a reasons for which is the changes in the fixed assets ratios of FÖTÁV Ltd. and their significant deviation from other heat suppliers observed over the years. The asset structure of privately owned district heating companies differs significantly from the financial reports of companies owned directly or indirectly by local municipalities. The fixed asset ratio is 13-20 percentage point lower for these companies, depending on the year [17].

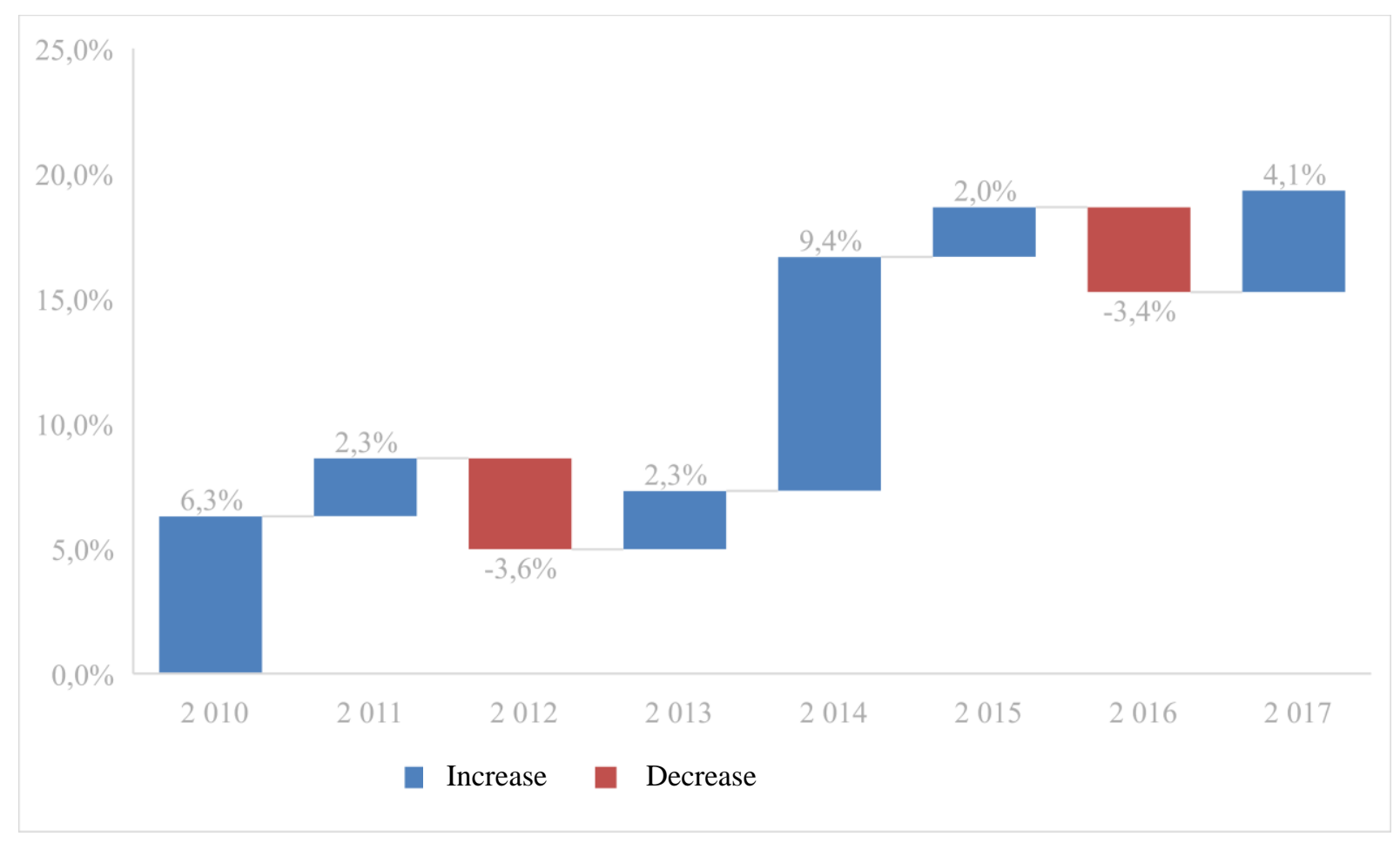

Figure 2. Change in the absolute value of fixed assets Source: own compilation

The tangible assets of companies providing district heat supply increased by only $19 \%$ on average during the examined nine years, which is equal to an average annual increase of $2.23 \%$ (when we take into account the assets more closely related to the activity, the overall increase was $26 \%$, which corresponds to an average annual change of $3.22 \%$ ). Comparing these data with the consumer price index, the rate of replacement corresponds only to the rate of inflation (the annual average consumer price index is $2.32 \%$ in the examined period and $20.09 \%$ in the whole period). For the district heating sector as a whole, the replacement of tangible assets on average only slightly exceeds the amount of affected depreciation during the examined period, which raises concern. As the depreciation set by the Act on Accounting does not deal with inflation, in many cases new investments slightly exceed the amount of depreciation determined on the basis of the cost 20-40 years ago, which presumably does not cover their full replacement value. (Sufficient level of maintenance is realized when it would be about companies established in 2009 , but this is not the case with heat suppliers, as the majority of systems has been operating for $20-40$ years.) 
Not only the average investment rate, but also its trend draws the attention of responsible companies and decision-makers to danger. Between 2010 and 2014, the value of tangible assets increased by $16.41 \%$ (annual 3.09\% on average), but the growth slowed after 2014 and the increase was only $2.52 \%$ (annual average growth of $0.83 \%$ ) between 2014 and 2017. The increase of assets was greater for the sector as a whole in 2014, which is due to the fact that the investments started in the previous years - of which some were realized from tender sources like Environment and Energy Operational Program (KEOP) were activated for several companies in 2014. Although the 2012 government decree requires profit excessing $2 \%$ of the gross asset value to be spent on investments to increase energy efficiency, the regulatory system as a whole does not seem to provide an incentive for companies to invest, which carries a serious risk to achieve sustainable, long-term, and safe operations.

The activity of companies carrying out district heating supply tasks may be examined by indicators that characterize the entities independently from the data of the balance sheet and the profit and loss report. Appendix 4. of the Government Decree No. 157/2005 (VIII.15) on the implementation of Act XVIII. of 2005 specifies the data that should be provided by district heating suppliers annually.

The technical and economic information that have to be published mandatorily and that describe the operation of the district heat suppliers, include data about investments owned by the service provider, and therefore make it possible to analyze the distribution of activated investments.

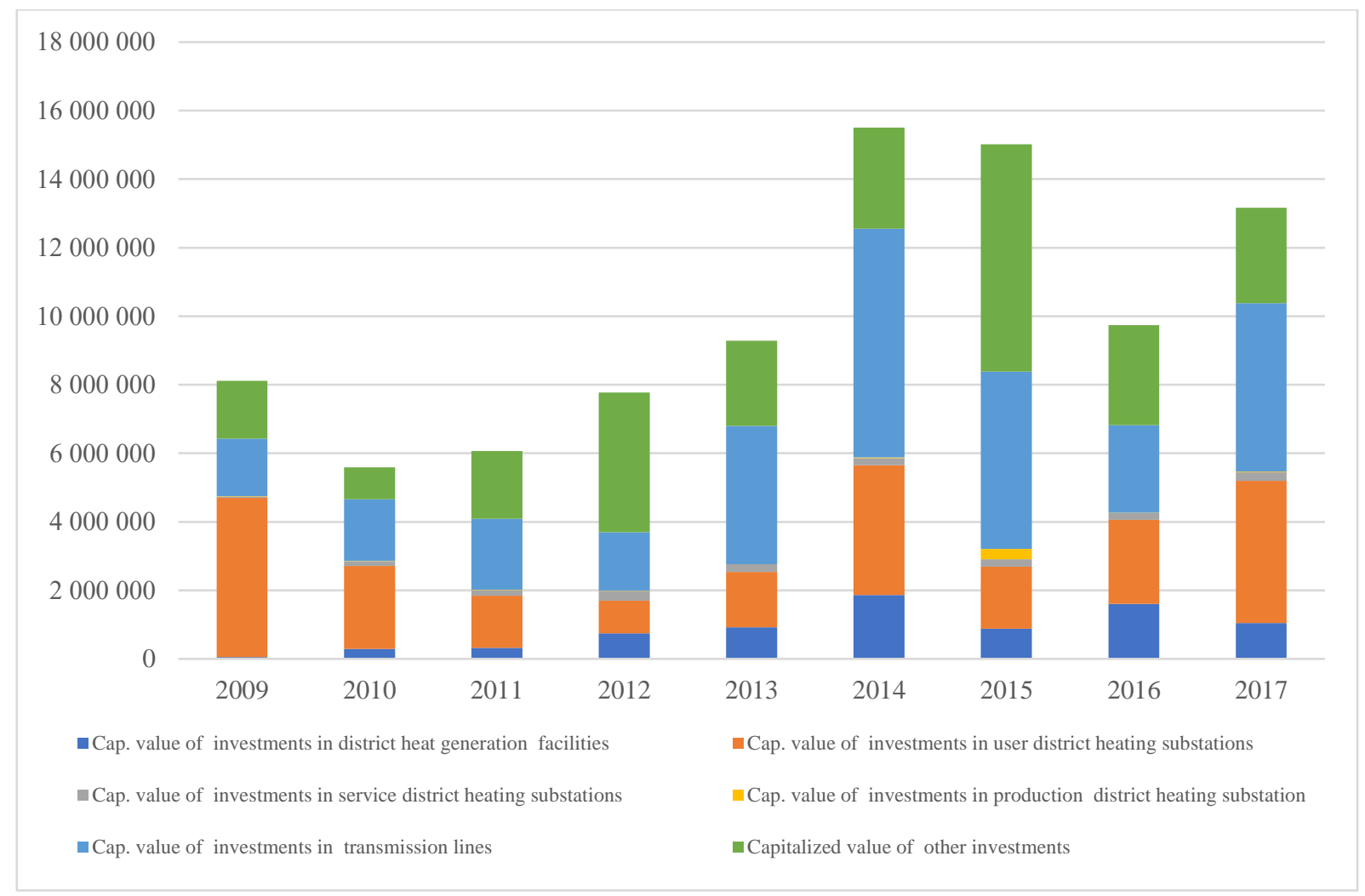

Figure 3. Distribution of capitalized investments of companies providing district heat supply (in thousand HUF)

Source: own compilation 
It is not possible to compare the absolute values of the investments in the figure, as data were available for fewer companies before 2013, however, the distributions within each year can also provide valuable information even in previous periods. Of the companies' investments in district heating services, the costs related to the installation and renovation of transmission lines accounted for the largest share, which implies that the replacement of old, often inadequately insulated networks is realized continuously. The second largest part belonged to the investments related to the modernization of user district heating substation. Assets belonging to these two technical categories make up the largest part of the district heating assets. The level of capitalized values of district heat producing facilities spent on investments is relatively low, which is due to the fact that not all heat suppliers produce their own heat.

The amounts spent on the development of service and production district heating substations form a minimal part of the total investment activity. In line with the objectives set by the National Energy Strategy, several innovative investments have been made in the district heating sector in recent years to develop environmentally friendly and efficient, energy-saving district heating systems.

\section{Summary}

Fixed assets make up the largest proportion of the asset structure of companies carrying out district heating supply activities. In order to ensure sustainable, long-term, and safe operation it is important to replace these assets on a regular basis.

The assets of the companies carrying out district heating supply activities grew only by 19 percent during the nine years of the study, which means an annual average of 2,23\% (if we take only the assets directly related to the district heating supply activity the growth is $26 \%$, which is an annual average of $3,22 \%)$. Comparing the data to the consumer price index we can conclude that the extent of replacement does not exceed the rate of inflation (annual average consumer price index in the period of study: 2,32\%; in the whole period: $20,09 \%$ ). We can conclude that the replacement of assets in the district heating sector in the time period of the study only slightly exceed the extent of accounted depreciation, which is a major concern. According to my calculations, in the period of the study the investment activity in the sector, considering the average age of the assets used in the district heating supply, was not satisfactory. The current regulatory and support system does not encourage replacement, improvements and modernization. Further research shall focus on the extent to which different companies form a homogeneous picture in this regard. Explanatory variables can include sales size, activities performed, ownership, existence of own heat production, and the region in which they operate.

\section{Acknowledgements}

The research reported here was carried out as part of the EFOP-3.6.1-16-2016-00011 "Younger and Renewing University - Innovative Knowledge City - Institutional development of the University of Miskolc aiming at intelligent specialization" project implemented in the framework of the Szechenyi 2020 program. The realization of this project is supported by the European Union, co-financed by the European Social Fund.

\section{References}

[1] Illés, M.: A közszolgáltató vállalatok gazdasági szabályozása, Aula Kiadó, Budapest, 2000. p. 235.

[2] Szendi, D.: The social innovation potential of the Northern Hungarian Region, European Journal of Social Sciences 3 (3), (2020) pp. 98-113. 
[3] Mabberley, J.: Pénzügyi intézmények controllingja, Panem Könyvkiadó Kft., Budapest, 1999. p. 301. (ISBN-963-545-191-1)

[4] Musinszki, Z.: Költség-e a költség? Költségek a vezetöi számvitelben, Controller Info 2, (2013) pp. 2-8.

[5] Musinszki, Z.: Költségallokációs problémák és megoldások, Controller Info 3 (4) pp. 2-10.

[6] Sinkovics, A.: Vállalati pénzügyi tervezés, Complex Kiadó Jogi és Üzleti Tartalomszolgáltató Kft., Budapest, 2010. p. 294. (ISBN-978-963-295-101-0)

[7] Siklósi, Á., Veress, A.: Könyvvezetés és beszámolókészités, SALDO Pénzügyi Tanácsadó és Informatikai Zrt., Budapest, 2016. p. 304. (ISBN-978-963-638-517-0)

[8] Béhm, I., Bárczi, J., Hágen, I.: A vállalkozási pénzügyi teljesitmény mérésére és értékelésére felhasznált mutatók a KKV-k beszámolási rendszerébe az új számviteli törvény figyelembevételével (II. rész), Controller Info 4 (4), (2016) pp. 44-52.

[9] Szemán, J.: Tökeszerkezeti elméletek érvényesülése a szolgáltató szektorban, Controller Info 5 (3), (2017) pp. 50-61.

[10] 2000. évi C. törvény a számvitelröl

[11] Pál, T, Várkonyiné, J. M., Füredi-Fülöp, J.: A könyvvizsgáló és a vállalati müködés, Controller Info 3 (4), (2015) pp. 15-21.

[12] 50/2011. (IX. 30.) értékesített távhő árának, valamint a lakossági felhasználónak és a külön kezelt intézménynek nyújtott távhőszolgáltatás díjának megállapításáról

[13] IAS 16 Property, Plant and Equipment; https://www.ifrs.org/issued-standards/list-ofstandards/ias-16-property-plant-and-equipment/

[14] Fodor, K.: Using multivariate statistical methods for analysing financial literacy, as a possible appearance of social innovation, Theory Methodology Practice: Club of Economics in Miskolc 16 (01), (2020) pp. 11-18. https://doi.org/10.18096/TMP.2020.01.02

[15] Süveges, G.: Analysis of the asset structure of hungarian district heat suppliers, with special regard to the fixed assets, based on the companies' 2009-2017 accounts, Theory Methodology Practice: Club of Economics in Miskolc 16 (01), (2020) pp. 53-63. https://doi.org/10.18096/TMP.2020.01.06

[16] Kucsma, D.: Performance management features in the light of social innovation in the public sector. In: Nemec, R., Chytilova, L. (szerk.) Proceedings of the 13th International Conference on Strategic Management and its Support by Information Systems 2019 (SMSIS 2019) Ostrava, Csehország : VSB-Technical University of Ostrava, pp. 42-50. Paper: SA/12, 9 p.

[17] Süveges, G.: Regional characteristics of hungarian district heating companies based on their 2009-2017 financial reports, with special regard to the rate of accounts receivable and to the energy efficiency of household consumers, Észak-Magyarországi Stratégiai Füzetek 17 (1), (2020) pp. 4-16., 13 p. https://doi.org/10.32976/stratfuz.2020.1 